\title{
Identification of Maintainers and Restorers for Development of Medium Slender and Short Grain Aromatic Rice Hybrids
}

\author{
Ashish Kumar Tiwari*, Sonal Upadhyay and Deepak Sharma \\ Department of Genetics and Plant Breeding, IGKV, Raipur (C.G.) 492012, India \\ *Corresponding author
}

\begin{tabular}{|c|c|}
\hline & A B S T R A C T \\
\hline & A study was undertaken to identify maintainers and restorers for their utilization in \\
\hline Keywords & $\begin{array}{l}\text { development of aromatic rice hybrids. The availability of stable cytoplasmic male sterility } \\
\text { and fertility restoring system is vital for commercial exploitation of heterosis in rice; it }\end{array}$ \\
\hline $\begin{array}{l}\text { Rice, Pollen } \\
\text { sterility, Spikelet } \\
\text { fertility, Maintainer, } \\
\text { Restorer }\end{array}$ & $\begin{array}{l}\text { means CMS is a common phenomenon that has been extensively used for production of } \\
\text { hybrid seeds in rice crop. Total } 60 \text { test crosses were evaluated for identification of } \\
\text { restorers and maintainers. These } 60 \text { test crosses were attempted with crossing of } 20 \\
\text { aromatic rice genotypes (testers) and } 3 \text { CMS lines. From these } 60 \text { test crosses } 8 \text { restorers }\end{array}$ \\
\hline Article Info & and 10 maintainers were identified for use in aromatic hybrid rice breeding programme. \\
\hline $\begin{array}{l}\text { Accepted: } \\
12 \text { May } 2020 \\
\text { Available Online: } \\
10 \text { June } 2020\end{array}$ & $\begin{array}{l}\text { Most of the genotypes were found partial restorers and partial maintainers. In this study } \\
\text { more numbers of maintainers were identified, is a key finding, these identified maintainer } \\
\text { will be used to develop fine grain aromatic stable CMS lines. Most of the CMS lines } \\
\text { developed so far are long slender or coarse grain non aromatic type. The CMS lines will be } \\
\text { developed from this breeding programme are fine grain aromatic type. }\end{array}$ \\
\hline
\end{tabular}

\section{Introduction}

Rice is the most important staple food crop in the world which plays major role in Indian economy. More than $90 \%$ of the world's rice is grown and consumed in Asia. For increased rice production and productivity, development and dissemination of hybrid rice technology has played as major and vital role. The use of cytoplasmic genetic male sterility system for developing hybrids in crops is possible only when effective maintainers and restorers are identified. Use of male sterility system would be appropriate approach for commercial exploitation of heterosis.
CMS system is controlled by the interaction of cytoplasm with nuclear genes (Kaul 1997). Chhattisgarh state has rich genetic diversity of aromatic rice traditional varieties, majority of them having small to medium slender grains.

These rices possessing unique aroma, cooking and eating qualities are consumed locally as a delicacy, therefore these rices fetches very high price in the market. These aromatic local varieties are very tall and late maturing. Due to taller stature they are prone to lodging at the time of booting to maturity stage, which is responsible for its poor yield. Due to late maturity they require high inputs as well more 
care for their cultivation. Through the use of hybrid technology it is possible to develop high yielding aromatic medium slender to short grain hybrid varieties. Development of a hybrid in rice using CMS requires identification of a male sterile line (A-line) a maintainer line (B-line) and a restorer line (Rline) (Madhuri et.al, 2018). Test cross programmes helps to identify maintainers as well as restorers. Maintainer lines for CMS development and restorer lines use as a male parent in hybrid development programme.

\section{Materials and Methods}

\section{Experimental site}

The experiment was conducted at Director cum Instructional farm, Indira Gandhi Krishi Vishwavidyalaya, Raipur, Chhattisgarh.

\section{Materials}

Twenty aromatic rice genotypes including traditional varieties/land races, and farmers' varieties were crossed with three CMS lines (Table-1) in Line $\mathrm{x}$ Tester fashion to generated 60 test crosses.

\section{Nursery sowing}

The three CMS lines and twenty testers were sown in nursery bed during Kharif-20182019. Staggered sowing of parent material was done to synchronize the flowering during hybridization. The 21 days old seedlings were transplanted.

\section{Hybridization}

Selected 20 testers were crossed with each of the three CMS lines to generate a set of hybrids in a line $\mathrm{x}$ tester manner as proposed by Kempthorne (1957). In order to increase the seed setting, the spikelet's of CMS plant that were expected to flower the next day were clipped one third at the top. The clipped panicles were completely covered with butter paper bags to avoid outside pollen grains. In the next morning (about 8:30 am) panicles from the male parents (testers) were collected during anthesis and were kept in pollination room at temperature of $40^{\circ} \mathrm{C}$ under high humidity in glass bottles.

After the completion of anthesis the pollen grains were carefully dusted over clipped spikelets. The pollinated panicles were immediately bagged again and labelled properly mentioning the date and cross combination. In this manner, 60 crosses were attempted for the present study.

The bagged panicles were harvested and separated from mother plants after 30-35 days of hybridization. The hybrid seeds of each cross were collected separately and sun dried. The seeds were treated with bavistin as a precautionary measure against fungal attack before storing in paper bags.

\section{Raising $F_{1}$ 's and parents}

During Rabi 2018-19, the treated seeds of the 60 hybrids generated during the previous season were carefully germinated in nursery beds. Three CMS lines (A lines/male sterile lines) and their isogenic lines (Maintainer/B lines) along with 20 elite testers (pollen parents) were also sown in nursery beds on the same day.

\section{Planting of $F_{1}$ 's and parents in Kharif 2019}

About 21 days old seedlings of 60 Test cross hybrids were planted in Randomized Complete Block Design (RCBD) design with their 23 parents (3 lines along with the isogenic B lines and 20 testers).

The distance between row to row and plant to plant was $20 \times 20 \mathrm{~cm}$ and keeping single 
seedlings per hills in 2.4 meter row length. Transplanting of material was done manually with standard agronomic package practices were adopted to raise ideal crop stand.

\section{Estimation of pollen testing}

Testing of pollen fertility of the test cross $F_{1}$ was carried out for their fertility or sterility responses. The spikelets (5 to 10) from the just emerged panicle of 3 randomly selected plants were collected in vial containing 70 percent ethanol. With the help of forceps, the anthers from the spikelets were placed on a glass slide containing 2\% Iodine Potassium Iodide (IKI) strain. Then the anthers were gently crushed by using needle to release the pollen grains. After removing the debris, a covers lip was put on the slide and observed under microscope. Five panicles of each testcross were covered with butter paper bags to avoid foreign pollen contamination and were harvested at maturity for recording spikelet fertility/sterility observation. The following criteria for classifying the parental lines as maintainers and restorers were used as proposed by Virmani et al., (1997).

\section{Table.A Criteria for classification of restorer and maintainers based on pollen fertility/sterility basis}

\begin{tabular}{|l|l|l|}
\hline Category & $\begin{array}{l}\text { Pollen fertility } \\
(\boldsymbol{\%})\end{array}$ & $\begin{array}{l}\text { Spikelet } \\
\text { fertility }(\%)\end{array}$ \\
\hline Maintainers & $0-1$ & 0 \\
\hline $\begin{array}{l}\text { Partial } \\
\text { maintainers }\end{array}$ & $1.1-50$ & $0.1-50$ \\
\hline $\begin{array}{l}\text { Partial } \\
\text { restorers }\end{array}$ & $50.1-80$ & $50.1-75$ \\
\hline Restorers & $>80$ & $>75$ \\
\hline
\end{tabular}

Only two characters like pollen sterility percentage and spikelet ferity percentage were recorded to identify maintainers and restorers of CMS lines/test crosses. The following formula were used to calculate pollen sterility and spikelet fertility (\%)

\section{Estimation of pollen sterility percentage}

Pollen fertility percentage will be calculated by formula: - (Virmani et al., 1997)

$$
=\frac{\text { No. of stained pollen }}{\text { Total no. of pollens }} \times 100
$$

\section{Estimation of spikelet fertility}

Estimation was done on three panicles per plant (two selected at random and one from the main culm) from five randomly selected plants for each test cross hybrid at maturity. Spikelet fertility of hybrids was assessed by taking the count of well filled and chaffy spikelet in each panicle. Spiklet fertility was estimated on B lines

$$
=\frac{\text { Number of fertile grains }}{\text { Total number of grains observed }} \times 100
$$

\section{Results and Discussion}

The establishment of test cross nursery to identify restorers and maintainers is the initial step in three line hybrid rice breeding programme. Results of pollen sterility and fertility are shown in Tables 2. Among the 60 rice genotypes different levels of pollen sterility and fertility were observed.

Such variation in pollen fertility indicated the existence genetic variation in respect of these reproductive traits among the genotypes. The pollen fertility percent of $\mathrm{F}_{1} \mathrm{~s}$ varied from $0 \%$ to $98.5 \%$ and spikelet fertility ranged from $0 \%$ to $93.31 \%$. Similar observations have been reported by other researchers (Ali et al., 2014, Krishnalatha and Sharma 2012, Sharma et al., 2012). This variation may be due to the pollen fertility-restoring genes differ or their penetrance or expressivity differed with genotypes (Umadevi et al., 2010) or due to existence of modifiers genes. 
Table.1 Details of lines and testers used in the present study

\begin{tabular}{|l|l|l|l|}
\hline S.N. & Female Parent (Lines) & Cytoplasmic source & Source \\
\hline $\mathbf{1}$ & IR 58025A & Wild Abortive (WA) & IRRI, Manila, Philippines \\
\hline $\mathbf{2}$ & CRMS31A & Kalinga & CRRI, Cuttack, Orissa \\
\hline $\mathbf{3}$ & CRMS32A & Kalinga & CRRI, Cuttack, Orissa \\
\hline Male Parent (Testers) & KALA JEERA & Germplasm,Biodiversity center, IGKV, Raipur \\
\hline $\mathbf{1}$ & TILKASTURI & Germplasm,Biodiversity center, IGKV, Raipur \\
\hline $\mathbf{2}$ & DHANIYA PHOOL & Germplasm, Biodiversity center, IGKV, Raipur \\
\hline $\mathbf{3}$ & KASTURIBHOG & Krishi Vigyan Kendra, Ambikapur \\
\hline $\mathbf{4}$ & INDRABHES DUBRAJ & Farmers field, Arkar, Dhamtari \\
\hline $\mathbf{5}$ & ING & $\begin{array}{l}\text { College of Agriculture, Murjhar Farm, } \\
\text { raseoni,Balagat }\end{array}$ \\
\hline $\mathbf{6}$ & CHINNOR & Germplasm,Biodiversity Center, IGKV, Raipur \\
\hline $\mathbf{7}$ & TULSI MOGRA & Germplasm,Biodiversity Center, IGKV, Raipur \\
\hline $\mathbf{8}$ & KALIKAMOD & Krishi Vigayan Kendra, Janjgir-Champa \\
\hline $\mathbf{9}$ & RAMJEERA & Krishi Vigyan Kendra, Ambikapur \\
\hline $\mathbf{1 0}$ & DHANIYA DHAN & Krishi Vigyan Kendra, Ambikapur \\
\hline $\mathbf{1 1}$ & BASABHOG & Krishi Vigyan Kendra, Bilaspur \\
\hline $\mathbf{1 2}$ & SAMUNDCHINI & JNKVV, Jabalpur \\
\hline $\mathbf{1 3}$ & KALIMUCH & Germplasm, Biodiversity Center, IGKV, Raipur \\
\hline $\mathbf{1 4}$ & JAWAPHOOL & Germplasm, Biodiversity Center, IGKV, Raipur \\
\hline $\mathbf{1 5}$ & TARUNBHOG & Krishi Vigyan Kendra, Dhamtari \\
\hline $\mathbf{1 6}$ & NAGRI DUBRAJ & Krishi Vigyan Kendra, Ambikapur \\
\hline $\mathbf{1 7}$ & JAU PHOOL & Dharohar Samiti, Kondagaon \\
\hline $\mathbf{1 8}$ & DAGRI KAJAR & Germplasm, G\& PB, IGKV, Raipur \\
\hline $\mathbf{1 9}$ & TULSI BHOG & Germplasm, Biodiversity Center, IGKV, Raipur \\
\hline $\mathbf{2 0}$ & BARHASAL & \multicolumn{2}{|l}{} \\
\hline & &
\end{tabular}

These hybrids were evaluated in Kharif 2018 for their spikelet and pollen fertility. All the three CMS lines used in our experiment showed various degrees of spiklet's fertility. Among the 20 parents derived from IR58025A, 2 parents (10\%) were found to be restorers and the number of maintainers was also $2(10 \%)$. Six $(30 \%)$ parents showed partial restorability and $10(50 \%)$ behaved as partial maintainers against this line. Out of 20 parents, 4 parents were (20\%) behaved as restorers and $05(25 \%)$ parents as maintainers with CMS line CRMS 31A. Number of parents showing partial restorability was 01 $(5 \%)$ and that behaving as partial maintainers were $10(50 \%)$ for CRMS 31A. However among 20 parents with CRMS 32A, 3 (15\%) parents showed as maintainers and $02(10 \%)$ parents were identified as restorers. Partial maintainers were $13(65 \%)$ and $02(10 \%)$ parents were behaved like partial restorers. (Figure 1, 2 and 3). Based on the overall $\mathrm{F}_{1}$ 's evaluation of 60 crosses derived from all the three CMS lines, 08 (13.3\%) crosses were found to have effective restorability (spikelet fertility $>75 \%$ ), while $09(15 \%)$ crosses were partial restorability (50.1 to $75 \%$ spikelet fertility), 33 (55\%) behaved as partial sterility (0.1 to 50\% spikelet fertility) and $10(16.7 \%)$ crosses were showed $100 \%$ sterility and tester parents involved in these crosses were considered as maintainer lines $(0 \%$ spikelet fertility). However using diverse CMS lines in testcrosses can give much validity to such fertility restoration studies (Das et al., 2013 and Prashad et al., 2017). 
Table.2 Fertility restoration and other characteristics for identification of restorers and maintainers among 20 testers and 03 CMS lines

\begin{tabular}{|c|c|c|c|c|c|c|c|c|c|c|}
\hline S.No. & PARENTS & 1 & 2 & 3 & 4 & 5 & 6 & 7 & 8 & 9 \\
\hline \multicolumn{11}{|c|}{ IR58025A } \\
\hline 1 & KALA JEERA & 87 & 118 & 10 & 8 & 58 & 76 & 71 & 147 & 51.70 \\
\hline 2 & TILKASTURI & 86 & 116 & 6 & 4 & 25 & 35 & 128 & 163 & 21.47 \\
\hline 3 & DHANIYA PHOOL & 86 & 115 & 7 & 5 & 25 & 36 & 137 & 173 & 20.81 \\
\hline 4 & KASTURIBHOG & 86 & 128 & 7 & 5 & 25.7 & 52 & 145 & 197 & 26.40 \\
\hline 5 & INDRABHES DUBRAJ & 88 & 79 & 12 & 10 & 98.5 & 265 & 19 & 284 & 93.31 \\
\hline 6 & CHINNOR & 85 & 123 & 8 & 0 & 0 & 0 & 129 & 129 & 0.00 \\
\hline 7 & TULSI .MOGRA & 80 & 122 & 13 & 10 & 40 & 54 & 110 & 164 & 32.93 \\
\hline 8 & KALIKAMOD & 78 & 120 & 12 & 9 & 45 & 54 & 91 & 145 & 37.24 \\
\hline 9 & RAMJEERA & 81 & 131 & 8 & 6 & 38 & 65 & 131 & 196 & 33.16 \\
\hline 10 & DHANIYA DHAN & 84 & 126 & 8 & 5 & 40 & 77 & 147 & 224 & 34.38 \\
\hline 11 & BASABHOG-F $F_{1}$ & 83 & 118 & 13 & 8 & 52.5 & 98 & 95 & 193 & 50.78 \\
\hline 12 & SAMUNDCHINI & 82 & 128 & 12 & 7 & 50 & 92 & 113 & 205 & 44.88 \\
\hline 13 & KALIMUCH & 83 & 112 & 10 & 8 & 45 & 59 & 80 & 139 & 42.45 \\
\hline 14 & JAWAPHOOL & 83 & 110 & 7 & 6 & 58.5 & 94 & 81 & 175 & 53.71 \\
\hline 15 & TARUNBHOG & 85 & 115 & 8 & 5 & 30 & 82 & 158 & 240 & 34.17 \\
\hline 16 & NAGRI DUBRAJ & 84 & 108 & 10 & 10 & 90.6 & 218 & 41 & 259 & 84.17 \\
\hline 17 & JAW PHOOL & 83 & 109 & 7 & 5 & 60.5 & 61 & 55 & 116 & 52.59 \\
\hline 18 & DAGRI KAJAR & 80 & 108 & 13 & 0 & 0 & 0 & 136 & 136 & 0.00 \\
\hline 19 & TULSI BHOG & 84 & 116 & 14 & 8 & 40.6 & 64 & 111 & 175 & 36.57 \\
\hline 20 & BARHASAL & 84 & 112 & 13 & 7 & 20 & 32 & 145 & 177 & 18.08 \\
\hline \multicolumn{11}{|c|}{ CRMS31A } \\
\hline 1 & KALA JEERA & 83 & 120 & 10 & 0 & 0 & 0 & 143 & 143 & 0.00 \\
\hline 2 & TILKASTURI & 75 & 117 & 8 & 5 & 25.5 & 27 & 79 & 106 & 25.47 \\
\hline 3 & DHANIYA PHOOL & 79 & 119 & 7 & 5 & 40.2 & 54 & 90 & 144 & 37.50 \\
\hline 4 & KASTURIBHOG & 82 & 116 & 12 & 6 & 30.1 & 35 & 133 & 168 & 20.83 \\
\hline 5 & INDRABHES DUBRAJ & 87 & 84 & 12 & 12 & 95.7 & 224 & 22 & 246 & 91.06 \\
\hline 6 & CHINNOR & 84 & 107 & 7 & 0 & 0 & 0 & 219 & 219 & 0.00 \\
\hline 7 & TULSI .MOGRA & 83 & 108 & 8 & 4 & 45 & 66 & 110 & 176 & 37.50 \\
\hline 8 & KALIKAMOD & 83 & 119 & 9 & 5 & 15 & 23 & 167 & 190 & 12.11 \\
\hline 9 & RAMJEERA & 84 & 121 & 8 & 3 & 18.7 & 24 & 156 & 180 & 13.33 \\
\hline 10 & DHANIYA DHAN & 75 & 117 & 10 & 0 & 0 & 0 & 197 & 197 & 0.00 \\
\hline 11 & BASABHOG & 82 & 115 & 11 & 7 & 30.5 & 44 & 137 & 181 & 24.31 \\
\hline 12 & SAMUNDCHINI & 82 & 119 & 10 & 6 & 30.2 & 28 & 89 & 117 & 23.93 \\
\hline 13 & KALIMUCH & 75 & 111 & 10 & 9 & 65 & 127 & 56 & 183 & 69.40 \\
\hline 14 & JAWAPHOOL & 83 & 115 & 8 & 0 & 0 & 0 & 227 & 227 & 0.00 \\
\hline 15 & TARUNBHOG & 87 & 128 & 14 & 12 & 81 & 198 & 41 & 239 & 82.85 \\
\hline 16 & NAGRI DUBRAJ & 87 & 114 & 9 & 8 & 85 & 212 & 31 & 243 & 87.24 \\
\hline 17 & JAW PHOOL & 83 & 120 & 6 & 4 & 25 & 44 & 150 & 194 & 22.68 \\
\hline 18 & DAGRI KAJAR & 82 & 100 & 10 & 6 & 15 & 23 & 148 & 171 & 13.45 \\
\hline 19 & TULSI BHOG & 77 & 119 & 11 & 0 & 0 & 0 & 128 & 128 & 0.00 \\
\hline 20 & BARHASAL & 83 & 121 & 14 & 12 & 85 & 161 & 43 & 204 & 78.92 \\
\hline \multicolumn{11}{|c|}{ CRMS32A } \\
\hline 1 & KALA JEERA & 86 & 117 & 8 & 0 & 0 & 0 & 97 & 97 & 0.00 \\
\hline 2 & TILKASTURI & 83 & 110 & 7 & 0 & 0 & 0 & 108 & 108 & 0.00 \\
\hline 3 & DHANIYA PHOOL & 84 & 125 & 8 & 6 & 40.5 & 38 & 79 & 117 & 32.48 \\
\hline 4 & KASTURIBHOG & 78 & 121 & 6 & 6 & 30.5 & 43 & 157 & 200 & 21.50 \\
\hline
\end{tabular}




\begin{tabular}{|r|l|r|r|r|r|r|r|r|r|r|}
\hline $\mathbf{5}$ & INDRABHES DUBRAJ & 87 & 83 & 8 & 8 & 96 & 253 & 25 & 278 & 91.01 \\
\hline $\mathbf{6}$ & CHINNOR & 83 & 110 & 6 & 5 & 20 & 25 & 137 & 162 & 15.43 \\
\hline $\mathbf{7}$ & TULSI .MOGRA & 92 & 120 & 9 & 6 & 22.5 & 38 & 175 & 213 & 17.84 \\
\hline $\mathbf{8}$ & KALIKAMOD & 85 & 113 & 8 & 5 & 15 & 19 & 133 & 152 & 12.50 \\
\hline $\mathbf{9}$ & RAMJEERA & 86 & 114 & 6 & 0 & 0 & 0 & 120 & 120 & 0.00 \\
\hline $\mathbf{1 0}$ & DHANIYA DHAN & 85 & 114 & 8 & 8 & 55 & 83 & 77 & 160 & 51.88 \\
\hline $\mathbf{1 1}$ & BASABHOG & 87 & 119 & 8 & 6 & 18 & 18 & 107 & 125 & 14.40 \\
\hline $\mathbf{1 2}$ & SAMUNDCHINI & 80 & 113 & 10 & 6 & 15 & 21 & 126 & 147 & 14.29 \\
\hline $\mathbf{1 3}$ & KALIMUCH & 71 & 109 & 8 & 5 & 50 & 63 & 78 & 141 & 44.68 \\
\hline $\mathbf{1 4}$ & JAWAPHOOL & 81 & 114 & 6 & 4 & 30.5 & 41 & 113 & 154 & 26.62 \\
\hline $\mathbf{1 5}$ & TARUNBHOG & 82 & 117 & 8 & 6 & 45 & 93 & 113 & 206 & 45.15 \\
\hline $\mathbf{1 6}$ & NAGRI DUBRAJ & 79 & 109 & 10 & 8 & 82 & 221 & 39 & 260 & 85.00 \\
\hline $\mathbf{1 7}$ & JAW PHOOL & 87 & 115 & 7 & 5 & 30 & 34 & 98 & 132 & 25.76 \\
\hline $\mathbf{1 8}$ & DAGRI KAJAR & 84 & 97 & 8 & 6 & 15 & 49 & 237 & 286 & 17.13 \\
\hline $\mathbf{1 9}$ & TULSI BHOG & 83 & 112 & 10 & 7 & 15.5 & 20 & 116 & 136 & 14.71 \\
\hline $\mathbf{2 0}$ & BARHASAL & 86 & 118 & 12 & 8 & 65 & 83 & 51 & 134 & 61.94 \\
\hline
\end{tabular}

1. Days to $50 \%$ Flowering

5. Pollen Fertility (\%)

9. Spikelet Fertility (\%)
2. Plant height $(\mathrm{cm})$

6. Fertile spikelets/Panicle

4. Productive tillers/plant

8. Total Spikelets/Panicle

3. No. of Tillers/plant

7.Sterile spikelets/panicle

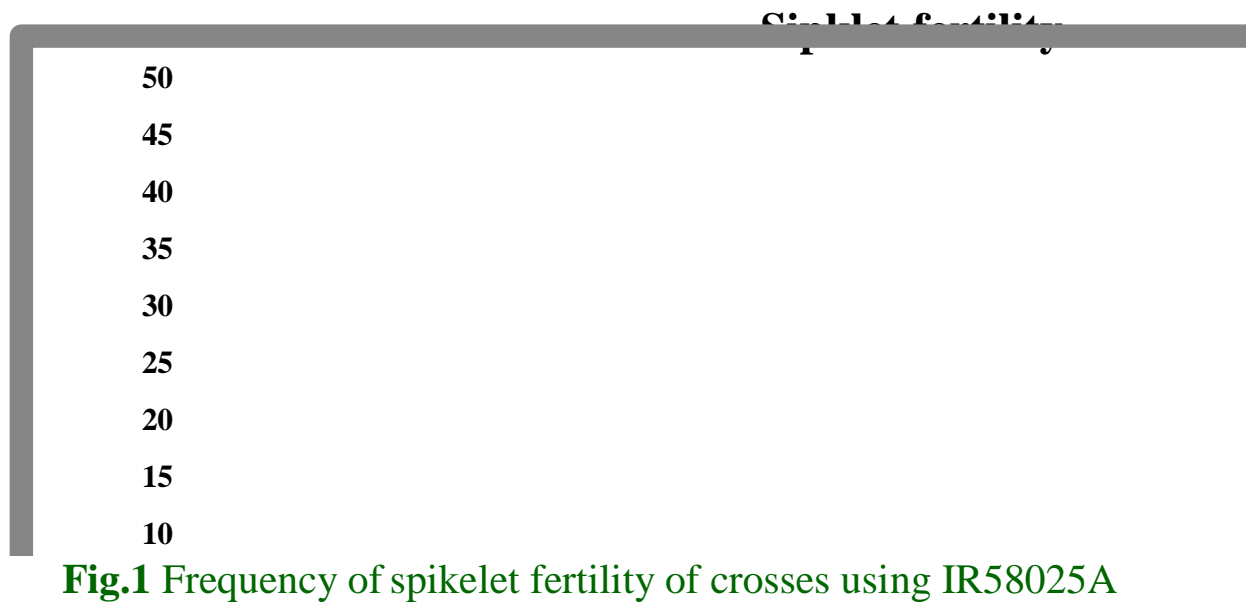

Fig.1 Frequency of spikelet fertility of crosses using IR58025A

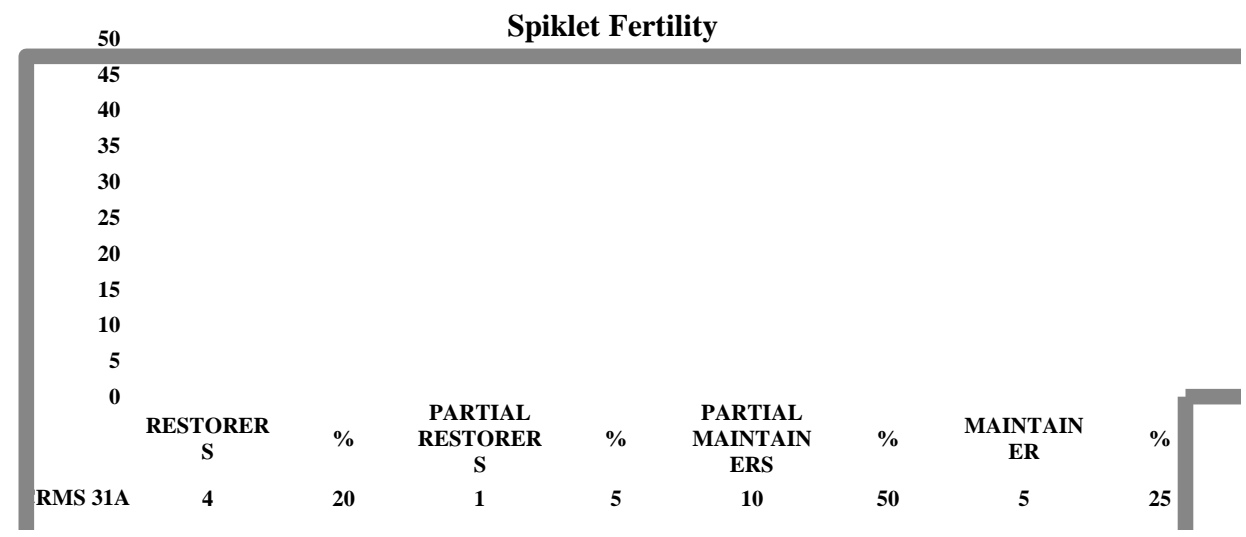

Fig.2 Frequency of spikelet fertility of crosses using CRMS 31A 


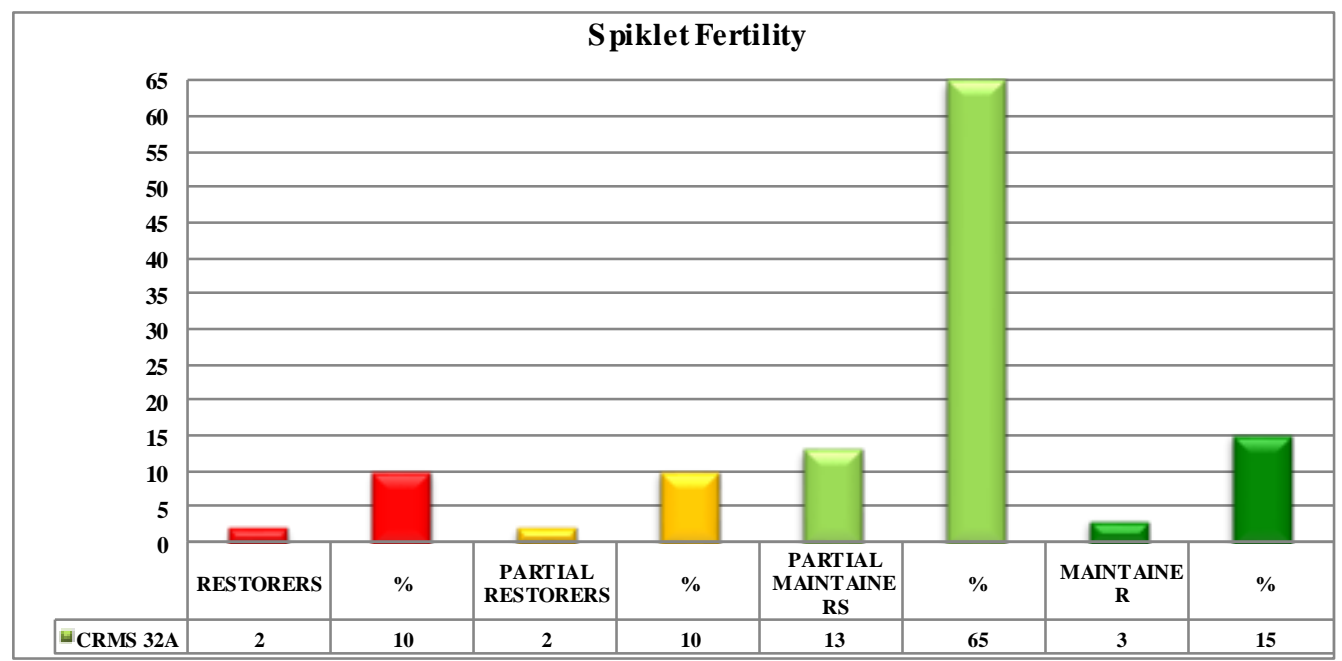

Fig.3 Frequency of spikelet fertility of crosses using CRMS 32A

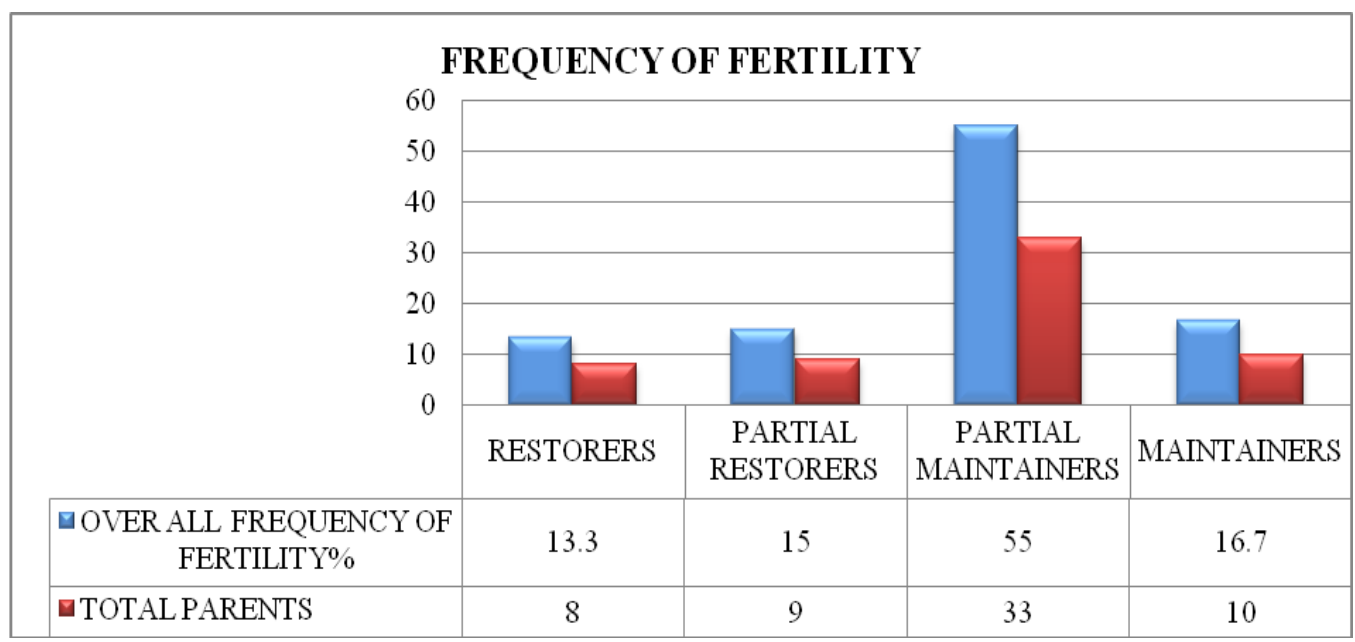

Fig.4 Frequency of restorers and maintainers

These 08 parents (restorers) can contribute for the development of good hybrids by utilizing the masparental lines. In general the frequency of partial restorers and maintainers were high. But more number of maintainers was identified as compare to restorers. Frequency of restorers and maintainers are presented in Fig.4.

Most interestingly Indrabhesh Dubraj and Nagri Dubraj both were commonly identified as restorers from all the three CMS lines viz. IR 58025A, CRMS 31A and CRMS 32 A. Strong restoration ability of these two parents is due to have two major genes along with modifier genes. Tarunbhog showed restorability with CMS line CRMS 32A and Barhasal. Whereas Chinnor was identified maintainer from two CMS lines viz. IR 58025A and CRMS 31A. Similarly Kalajeera was showed $100 \%$ sterility with CRMS 31A and CRMS 32A. Whereas other parents viz. Dagri Kajar expressed $100 \%$ sterility with IR 58025A, Jawaphool and Dhaniya Dhan showed $100 \%$ sterility with CRMS 31A. Tilkasturi and Ramjeera expressed 100\% sterility with CRMS 32A. The findings of the present investigation revealed that fertility restoration reaction of the genotypes varies with their genetic background. More 
emphasis should be given to utilize popular rice aromatic cultivars in hybrid rice breeding as parental lines to achieve the goal of superior hybrid with better grain quality.

The identified restorers are locally adopted. The identified maintainers can be developed as new members in cytoplasmic male sterile (CMS) family by repeated backcross breeding. This is prerequisite to develop aromatic medium slender and short grain hybrids. The CMS line must be devolved or converted as aromatic short grain type to produce such type of hybrids. Two parents viz. Indrabesh Dubraj and Nagri Dubraj were showed strong restorability with all the three CMS lines, may be due to two or more restorer gene with modifier. The identified restorer lines can be used as pollen parent in developing new commercial aromatic hybrid varieties. New restorer may also be developed through crossing programme which can expand the genetic base of restorer by pyramiding complementary traits from diverse sources according to breeding objectives. Ten aromatic medium slender maintainers identified from this study are one of the significant findings from this study. These maintainers will be converted into aromatic medium slender and short grain CMS lines after recurrent back crossing program which play major role in developing aromatic short grain hybrids.

\section{References}

Ali. M., Hossain, M.A., Hasan, M. J. and Kabir, M.E. 2014. Identification of maintainer and restorer lines in local aromatic rice. Bangladesh Journal of Agricultural Research 39 (1):1-12.

Das, P., Mukherjee, B., Santra, C.K., Mukhopadhyay, S. and Dasgupta, T. 2013. Evaluation of genotypes for fertility restoring and maintaining behaviors in rice (Oryza Sativa L.).
International Journal of Scientific and Technology Research 2 (11):228-232.

Kaul, M. L. H. 1997. Male sterility: cytological, biological and molecular alterations. In: Plant Breeding and Crop Improvement. Vol. (II) (Eds. Kapoor and Saini) CBS Publishers Distribution. New Delhi. 377-378Pp.

Krishnalatha, S. and Sharma, D. 2012. Identification of maintainers and restorers for WA and Kalinga sources of CMS lines in rice (Oryza sativa L.). Electronic Journal of Plant Breeding 3 (4):949-951.

Madhuri, R., Shivakumar, N., Lohithaswa, H. C. and Pavan, R. 2018. Identification of Potential Restorers and Maintainers from Newly Developed Parental Lines Based on Morpho-Floral Characters in Rice (Oryza sativa L.). Int.J.Curr. Microbiol. App. Sci. 7: 619-627

Prashad, R. K., RadhaKrishna, K. V., Kumar, S. S. and Rao, L. V. S. 2017. Identification of elite restorers and maintainers in rice based on pollen fertility and spiklet fertility studies. Int. J. Curr. Microbiol. App. Sci 6(8):26472651

Sharma, S.K., Singh, S.K., Nandan, R. and Kumar, M. 2012. Identification of restorers and maintainers for CMS lines of rice (Oryza sativa L.). Indian Journal of Plant Genetic Resource 25 (2):186188.

Virmani, S. S., Viraktamath, B. C., Casal, C. L., Toledo, R. S., Lopez, M. T. and Manalo. J.O. 1997. Hybrid Rice Breeading Manual. Intl. Rice Res. Inst. Los Banos, Leguna, Philippines. 155P.

Umadevi, M., Veerabadhiran, P., Manonmani, S. and Shanmuga, S.P. 2010. Identification of potential maintainers and restorers using cytoplasmic male sterile lines in rice. Electronic Journal of Plant Breeding 1 (4):948-952. 


\section{How to cite this article:}

Ashish Kumar Tiwari, Sonal Upadhyay and Deepak Sharma. 2020. Identification of Maintainers and Restorers for Development of Medium Slender and Short Grain Aromatic Rice Hybrids. Int.J.Curr.Microbiol.App.Sci. 9(06): 48-56.

doi: https://doi.org/10.20546/ijcmas.2020.906.006 